\title{
INTEGRATION OF ZAKAT AND TAX FOR ECONOMIC DEVELOPMENT
} INTEGRASI ZAKAT DAN PAJAK UNTUK PEMBANGUNAN EKONOMI

\author{
${ }^{1}$ J. Muharani, ${ }^{2}$ Nurhidayanti, ${ }^{3}$ A.R Hamdi \\ 1,2,3Universitas Islam Negeri Sumatera Utara, Jl. IAIN No. 1, Gaharu, Kec. Medan Timur, Kota \\ Medan, Sumatera Utara 20235 \\ E-mail: 1junitamuharaninst95@gmail.com, 2nury.nurhidayanti@gmail.com. \\ 3abdulhamdi621@yahoo.com
}

\begin{abstract}
This study aims to find integration between zakat and tax is an instrument for collecting funds is expected to help the country's economy, but today these instruments have not been realized completely due to thinking their double burden. The type of research uses literature study using secondary data. Results of the discussion stated that the synergy of the tax and zakat in Indonesia's economic development is very important, because the tax and zakat have complementary usefulness. With synergy of tax and zakat, the economic development that is formed is a strong economy and can compete in the midst of the economic crisis that threatens.
\end{abstract}

Keywords: zakat, tax, and economic development.

\begin{abstract}
ABSTRAK
Penelitian ini bertujuan untuk mengetahui keterpaduan antara zakat dan pajak yang merupakan instrumen penghimpun dana yang diharapkan dapat membantu perekonomian negara, namun saat ini instrumen tersebut belum terealisasi secara utuh dikarenakan pemikiran beban ganda mereka. Jenis penelitian menggunakan studi pustaka dengan menggunakan data sekunder. Hasil pembahasan menyatakan bahwa sinergi perpajakan dan zakat dalam pembangunan ekonomi Indonesia sangat penting, karena pajak dan zakat mempunyai kegunaan yang saling melengkapi. Dengan sinergi perpajakan dan zakat maka pembangunan ekonomi yang terbentuk merupakan ekonomi yang kuat dan mampu bersaing di tengah krisis ekonomi yang mengancam.
\end{abstract}

Kata kunci: Zakat, Pajak, dan Pembangunan Ekonomi.

Junita Muharani. 2020. Integrasi Zakat dan Pajak Untuk Wisuda. Jurnal Syarikah 6 (2): 197-. 


\section{PENDAHULUAN}

Zakat one of the pillars of Islam that obligation is absolute, of assets a person according to the rules that have been set in the Qur'an and Hadith. In the context of the modern state, charity is not a tax, which is one source of state revenue. Zakat was viewed as the primary means of communication between the rich with the poor, who have a very important role as a means of income distribution in order to organize the life of society that is prosperous, equitable within a country.

The position of zakat in Islam an advantage in the economic system of Islam. Zakat illustrate embodiments of a Muslim adherence to Khaliq. This is a manifestation of a Muslim solidarity in social life. So if prayer trying to establish an individual's personal piety, then zakat role in shaping social piety for each individual in masysrakat.

The correlation between the tax due, and both have the collection function in the life of the state. In zakat, the collection function can be performed by people affected by the obligation to pay zakat and can go directly to the people who deserve it or performed by an agency or official institutions such as Badan Amil Zakat (BAZ) or Lembaga Amil Zakat (LAZ), which was established by the government to collect and distribute zakat to the eight groups are eligible to receive zakat. While the tax levied functions performed by the State through the Directorate General of Taxation.

The fact that the subject of the largest tax are Muslims who number $87 \%$ of the total population of Indonesia, the government is trying to minimize the double burdensome obligations. Efforts to overcome the convergence between the tax and zakat so that both of these obligations can be implemented by Muslims without overloading it. The government makes the rules can be a solution to the dual obligation of zakat and taxation suffered by Muslims. It is stated in Article 22 of Law No.23 of 2011 on the change of Article 14 paragraph (3) of Law No.38 of 1999 concerning the Management of Zakat, mentioned:
Zakat which has been paid to the zakat agency ( amil zakat ) board or other zakat institutions deducted from profits / taxable residual income from the taxpayer concerned in accordance with the legislation in force.

This law shows that the government tried to play an active role in creating the religious obligations of the community by making charity as one of the elements of tax relief (tax relief) in the collection of Income Tax (VAT) in Indonesia. The current legislation makes charity as a deduction from the net income of the individual taxpayer (WPOP) in determining the amount of taxable income. This is expected to minimize the burden that in bear by Muslims as a taxpayer and muzakki. If in view of its basic functions to pay zakat can be equated in value to pay taxes which are equally intended to implement the obligations that aim to benefit the community and the nation.

\section{LITERATURE AND METHODS}

\section{Zakat}

According Yafie in Zuhirsyan (2016: 2) Zakat is one of worship maaliyah ijtima'iyyah (read: worship that is both material and social). Zakat has a position that is very urgent, strategic, and decisive both in terms of the teachings of Islam as well as the development of the welfare of the people. As a human worship, zakat is one pillar (third pillar) of the five pillars of Islam, as in the hadith of the prophet, so its existence is regarded as Ma'lum minad-deen-dharurah or unknown bidh automatically presence and an essential part of the Islamic someone.

In language zakat means an-numu wa az-ziyadah (grow and multiply). Sometimes applied to the meaning of ath-thaharah (sacred). Al-baraka (blessing). Zakat, in the sense of the sacred, is self-cleaning, life, and property. Someone who issued zakat means he has cleaned up and the soul of a miser's disease, clean up his property on the rights of others. Meanwhile, the charity within the meaning of the blessing is the rest of the treasure that has been issued qualitatively artanya will be blessed and will develop even quantitatively reduced amount. 
As for the meaning of the terminology of the terms used in the discussion of Islamic fiqh, zakat is issued as part of the treasure particular has reached nishab (certain dose which is the minimum limit of the property is required to be issued zakat), given to those who deserve it (by grouping contained in AlQur'an), and those assets belong to the perfect-in the sense of a self-owned and there are no other oanga ownership didalamnyaand fulfilled the age of ownership during the year, or what is known as the haul (Al wise, 2015: 278).

Zakat is the third pillar of Islam which are required in the second year of the Hijri according to most scholars. Subsections of zakat, alms and infaq revealed in Makkah those only form of encouragement and delivery methodology for conducting praise and scolding or reprimand to the left. The cornerstone obligation to pay zakat were from the al-Quran and Hadith. in the Koran which describes the obligation of zakat verse 43 surat al-Baqarah, verse 103 surat at-Taubah, and verse 141 surat al An'am.

While the Hadith into the proposition obligation of zakat of them are; the words of the Prophet narrated by Bukhari and Muslim from Abdullah ibn Umar: "Islam is built on five pillars: the Creed is no god except Allah and Muhammad the Messenger of God, upholding the prayers, pay Zakat, Hajj and fasting Ramadan." (HR. Bukhari Muslim).

Another tradition is, the history of athThabrani of Ali;

"God requires (zakat) on rich people from Muslims on their properties with corresponding boundary adequacy of the poor among them. Poor people will not be lacking when they are hungry or not dressed unless caused by the rich among them. Remember that God will menghisab them harshly and punish them with grievous. "(HR. AthThabrani)

According to the Law of the Republic of Indonesia Number 23 of 2011 which is a form of revision of Law No. 38 of 1999 on the Management of Zakat through BAZNAS, stated that zakat is an institution of religious whose aim is to improve the justice, public welfare, and poverty reduction, and therefore the charity must be well managed through BAZNAS for equitable distribution to achieve these goals.

Tax

According to Law No. 28 of 2007, article 1 , the tax is a mandatory contribution to the state owed by individuals or entities that are enforceable under the Act by not getting rewarded directly and used for the purposes of state for the greatest for people's welfare. Tax functions are divided into two, namely budgetair function or reception function and the function of income redistribution. The first function, as well as the economy of a household or family, the country's economy also recognize sources of revenue and expenditure items. Taxes are the main source of state revenue. Without the tax, most of the activities is difficult to be implemented. The use of tax covers ranging from personnel expenditure up to finance various development projects. Public infrastructure development funded using money from taxes. It is thus clear that the role of tax revenue for a country to be very dominant in supporting the wheels of government and development financing. (Handbook of Rights and Obligations of Taxation, 2009).

In Islamic law, the basic obligation to pay taxes (dharibah) is verse 29 surat AtTauba which means: "Fight those who believe not in Allah nor the Last Day, and they do not forbid what is forbidden by Allah and His Messenger and not the religion that is true (the religion of Allah), namely those that are given to them al the Book, until they pay 'Jizya' with obedient, they are in a state of subjection. " (QS. At-Taubah: 29),

The above paragraph is only impose the jizya (protection tax) against non-Muslims in both men and women are capable of receiving protection in Muslim countries. Meanwhile, people who can not afford freed from the burden. The assignment was adapted to the social status and their financial condition.

There are two opinions of scholars about taxes. Some scholars have that forbid taxes, but scholarly justify the tax. Among scholars who forbid tax refers to the hadith of 
the Prophet Muhammad from Uqbah bin Amir who asserts that: "It will not enter Paradise who picks muks". (HR. Abu Dawud, Al-Hakim, Ibn Khuzaimah of Muhammad bin Ishak history). Then from Abu Khair ra he said: "Maslamah bin Mukhallad -Governor of Egypt- refused to hand usyur (1/10) to Ruwaifi ibn Thabit, he said:" I heard the Prophet say that the owner muks was in hell. "(HR. Ahmad from Ibn history Luhaiah and Tabarani).

Scholars such as Muhammad Nasir alAlbani, Abdul Aziz bin Abdullah bin Baz, Muhammad ibn Salih al-'Utsaimin, and AdhDhahabi equate muks or usyur (1/10) as a tax or customs so that they proscribe tax and customs, and menfatwakan that tax officials and customs officers is commit major sins that will be punished and the return is hell.

Jumhur Ahl sunnah wal Jama'ah scholars of the four schools, Shafi'i, Hanafi, Maliki and Hanbali, argues muks usyur or can not be generalized as customs tax moreover. Etymologically, it means a reduction muks with persecution. So muks are all levies (money) taken by ma'kis (muks collector or collectors levy) from traders through ways unjust. They agreed that the tax collected / deducted by the government to fund and meet the needs of the community such as the financing availability of facilities, roads, bridges, public transport, drinking water, electricity, hospitals, government, generic pharmaceuticals, defense, security and public order by military and Police, the country's schools to the rural and remote areas.

\section{Method}

\section{Types of research}

Judging from the kind of research is included in a library research (library research), the research carried out by using the literature (literature) in the form of books, records. research derived from the Act, official documents, and the publication of scientific papers, By researching and reading books relating to the discussion material that aims to collect data information with the help of various materials on library diruang, because each study would require materials sourced from library.

\section{Data source}

Source of data used secondary data obtained from the writings of others related to the integration of the tax and zakat. As well as other secondary materials which include Law, results of scientific work, research etc.

\section{Method of collecting data}

The data collection begins with begins with the search activity of Islamic law and associated legislation and sources of positive law of a legal system that is relevant to the legal issue at hand, A study law in general has several approaches. In scientific writing, the writer collected data through sources available literature either from books, articles, scientific papers and other related research problems.

\section{Data analysis}

The data analysis using the comparative method is, to analyze the data by comparing the data with each other data to arrive at a point of conclusion aimed at addressing the problems that exist.

\section{HASIL DAN PEMBAHASAN}

The imposition of Zakat and Taxation of the same object, namely wealth or income is still a debate among Muslims, even today. Some think Zakat and Taxation can abort each other, so if you have to pay taxes no longer should pay Zakat, or vice versa. In fact, the Indonesian Ulema Council (MUI) has long remained berfatwa that Zakat obligatory for every Muslim even though the existing taxes.

However, to avoid double burden and considering the fairness of other religious communities, the government and the House agreed to exclude charity and other religious donations as taxable income for the recipient (mustahik). Moreover, zakat and other religious donations compulsory also designated as a deduction from taxable income for the payer (muzakki).

However, all this was not satisfactory to all parties, especially those who demanded that Zakat designated as a tax deduction as was applicable in Malaysia. Among other demands coming from the province of Aceh, which was granted special autonomy through Law No. 11 of 2006 on Governing Aceh (LOGA). In those mentioned that zakat is part of local revenues (PAD) be deductible from income tax. 
In the midst of the government's plan to revise the laws on taxation, one of which the Income Tax Act, the insistence that charity tax deduction made resurfaced. However, seprtinya difficult to achieve given the prevailing religion in Indonesia not only in Islam. In addition, each kewajibaan different religions associated with the donation. For example, Islam requires Zakat with an average level of $2.5 \%$, while other religions also require donations to different levels.

Under Law no. 17 of 2000 on tax Income Tax 17 paragraph (1) letter a and b, that zakat can lower double income tax. First, it reduces taxable income. Secondly, for certain values also decrease the progressive rates $^{1}$, Zakat as a deduction from income tax would be a positive influence on the level of aggregate consumption. Application of Law No. 17 of 2000 this will increase the average propensity to consume and the marginal propensity to consume is likely to be greater when compared with the average propensity to consume and the marginal propensity to consume without charity.

Savings is a direct difference between national income with aggregate consumption. Zakat commercial property will negatively affect savings. Average propensity to save and the propensity to save marginal variable commercial zakat is smaller than the average propensity to save and the marginal propensity to save without variable zakat. One of the underlying reasons why the charity negative effect on savings is when someone has savings and not circulated in the economy then the savings will be exhausted by the charity. The significance of these reasons is that Muslims do not accumulate wealth alone, but must rotate the property owned in order to be meaningful in the economy more widely to the economy of a country than if the wealth is only kept alone.

Investment is spending or spending the investors or companies to purchase capital goods and production equipment, in order to increase the ability to produce goods and services available in the economy. Zakat will

www.jdih.kemenkeu.go.id., "UU No. 17 Tahun 2000 Tentang Perubahan Ketiga Atas Undang-Undang No. 7 Tahun 1983 Tentang Pajak Penghasilan”. be a positive influence on the investment, because the obligation of zakat will stimulate Muslims to not hoard his money but to invest that wealth is rotating in the economy. But the investment in question here is the real investment not a financial investment. Although in general the charity as a deduction from taxable income has had an influence on the aggregate consumption, savings and investment, the impact is actually smaller when zakat is positioned as a component of income tax deduction.

Not surprisingly, many people who view the current rule where the charity as a deduction from taxable income and the tax burden actually causes the charity they must pay greater compared to only pay taxes only. Therefore, if the government has a genuine desire to develop Islamic economics and has considerable influence in the economy, then zakat should be placed as an income tax deduction. If the charity is placed as a deduction from the income tax, then he will have a greater impact to aggregate consumption, savings and investment compared to zakat only positioned as a deduction from taxable income.

One of the solutions and recommendations on the system of taxation and zakat in Indonesia in order to conform with the Islamic economic system that is integrated at the moment is the need to establish among other body or authority responsible for zakat and tax issues. In Sahih Bukhari narrated from Ibn Abbas friend was quoted as saying by Yusuf Al Qaradawi who explained the party responsible for the collection of zakat in the country is the government. The government's responsibility in zakat collection consists of:

1. Making the rules regarding the collection of zakat

2. To supervise the zakat paid by society,

3. Enforcing the law against those who are reluctant to pay zakat and pay zakat amount that is less than it should be, and managing zakat and distribute it to the parties entitled to receive,

In its development in the future, synergy pattern of tax and zakat is expected not only contained in the laws but needs other 
schemes applied, for example, there is collaboration BAZNAS program as a national charity official bodies and governments through taxation directorate. Program outreach programs, promotions, information in the media, for example, collaboration BAZNAS and Taxation Directorate in increasing tax revenue target charity or must do. Thus the benefits of increased zakat and tax receipts can be maximized so that a positive impact on poverty alleviation programs.

In Indonesia, zakat and taxation has not collaborate together. Zakat and tax management still stand each separately. Zakat held by zakat and taxes administered by the government. However, the calculation of zakat is inserted to be a tax credit in the Annual Tax. Haparan future, by making systematic improvements, Indonesia is perceived to be able to surpass other Muslim majority countries in terms of zakat and tax.

With the synergy of tax and zakat, the improvement of social welfare will increase both macro and micro. On the micro level, improvement of social welfare can be seen from the increase in per capita income that can be used to meet everyday needs. Meanwhile, the macro improvement of social welfare can be seen from the increasing number of public facilities both in terms of quality and quantity. Increased welfare of society as a macro driven by rising per capita

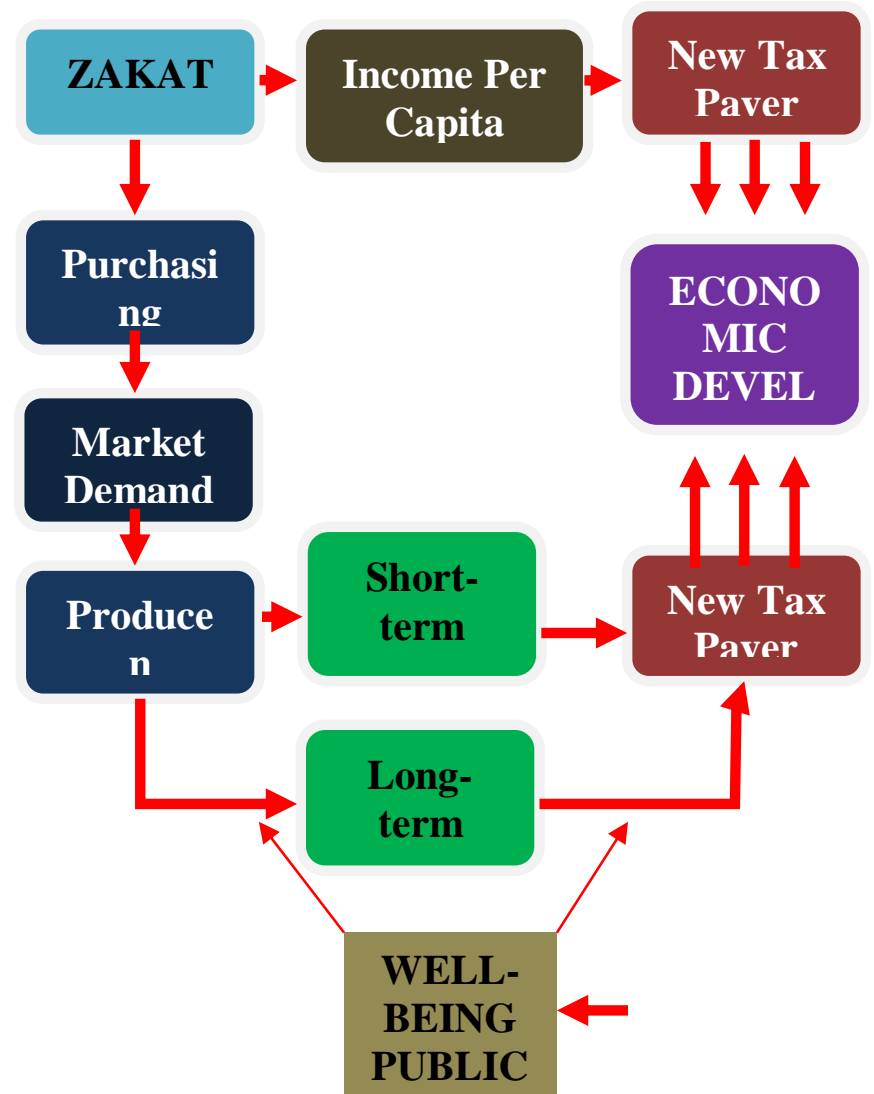

income that creates a new taxpayer so that state tax revenues increased. with increasing economic prosperity in micro and macro, so that economic development will be more rapid.

And the results of economic development will be beneficial to the people, Here is a chart that illustrates the multiplier effect of charity.Meanwhile, if zakat is given in the form of productive goods, then the charity will provide a long-term effect. Its multiplier effect was not much different with the charity given in the form of consumer goods. What distinguishes, namely productive charity provides opportunities for the poor to independently meet its own economic needs. Independence of the community is a longterm effect that can be the foundation of Indonesia's economy strong and competitive in the global economy. With the success of economic development, then the public welfare will increase both macro and micro.

multiplier effect of the tax itself more in favor of the macro sector. Increasing taxes will facilitate the government in economic development. Public facilities will be more and more and the quality is better than before. So the macro level, the welfare of society are met. Community wellbeing will flow again through the distribution of zakat and taxation of wealth.

\section{CONCLUSION}

Synergy tax and zakat in Indonesia's economic development is very important, because the tax and zakat have complementary usefulness. With synergy of tax and zakat, the economic development that is formed is a strong economy and can compete in the midst of the economic crisis that threatens. This is due to the strengthening of the micro sector are supported with alms. Zakat productive has long-term effects to create a powerful micro sector. With the zakat empowered productive for the micro sector it will potentially create taxpayer will increase state revenues from the tax sector. With increasing government revenue from tax sector. 


\section{DAFTAR PUSTAKA}

Ali, Zainuddin., "Metode Penellitian Hukum”, Jakarta: Sinar Grafika, 2011

Anton Bakker \& Achmad Charris Zubair, "Metodologi Penelitian Filsafat", Yogyakarta: Kanisius, 1990

Buku Panduan Hak dan Kewajiban Perpajakan, diterbitkan dalam bentuk ebook oleh Ditjen Pajak Kemenkeu RI, http://www.pajakonline.com/engine /learning/ view.php?id=765 diunduh 15 Januari 2020

Joko Subagyo, P., "Metode Penelitian dalam Teori dan Praktek", Jakarta: Rineka Cipta, 2006

M nur Rianto, Al Arif., “ Pengantar Ekonomi Syariah Teori dan Praktik".,

Nasution,S .,"Metode Research (Penelitian Ilmiah)", Jakarta: Bumi Aksara, 2012

Nur Rianto Al Arif, M., "Fungsionalisasi Zakat Dan Pajak Di Dalam Perekonomian" Jurnal Ekonomi Islam, FAI Universitas Muhammadiyah Prof. Dr. Hamka Volume 3, Nomor 1, April 2013

R. Ramadhan, M,. "Integrasi Pajak Dan Zakat Di Indonesia". Islamiconomic: Jurnal Ekonomi Islam, 2017, 8, 77-94.

Rozalinda., "Fiqh Ekonomi Syariah"

Sartika, M. Pengaruh Pendayagunaan Zakat Produktif terhadap Pemberdayaan Mustahiq pada LAZ Yayasan SoloPeduli Surakarta. Jurnal EKonomi Islam "La Riba". Vol. II, No. 1, Juli 2008

Susiadi, "Metode Penelitian", Bandar Lampung: LP2M Institut Agama Islam Negeri Raden Intan Lampung, 2015

Wijono, W.W., Sumber-Sumber Pendapatan Ekonomi, Jurnal Manajemen dan Fiskal Vol V, No. 2 Jakarta 2010.

www.jdih.kemenkeu.go.id., "UU No. 17 Tahun 2000 Tentang Perubahan Ketiga Atas Undang-Undang No. 7 Tahun 1983 Tentang Pajak Penghasilan".

www.republika.co.id "peran pajak dan zakat ditengah ketimpangan ekonomi" diunduh tgl 03 maret 2020 pukul 22.07 wib

Y Afriyandi,. "sinergitas Pajak dan Zakat Dalam Keuangan Publik Islam". Rasail, 2014, 2(1), 279.
Zuhirsyan, Muhammad.," Menejemen Zakat, Infaq, Religiusitas, dan Waqaf" 